\title{
PENGARUH KUALITAS LAYANAN TERHADAP CITRA PERUSAHAAN, KEPUASAN DAN LOYALITAS PELANGGAN (Studi pada Nasabah Pengguna Produk Tabungan BCA di wilayah Rungkut Mapan, Surabaya)
}

\author{
${ }^{1)}$ Luthfy Purnanta Anzie, ${ }^{2}$ Zainul Arifin \\ ${ }^{12)}$ Fakultas Ilmu Administrasi Universitas Brawijaya, Malang \\ ${ }^{1)}$ E-mail : luthfypurnanta@yahoo.co.id
}

\begin{abstract}
The purpose of this research was to investigate and explain the significant effect of service quality on corporate image, service quality on customer satisfaction, service quality on customer loyalty, corporate image on customer loyalty, corporate image on customer satisfaction and to customer satisfaction on customer loyalty. This research is an explanatory research that explains the causal relationships between variables by using a quantitative approach. Generalized Structured Component Analysis (GSCA) is used as a method of data analysis, accompanied by hypothesis testing to determine significant effect on the variables that have been determined. Population taken as many as 55 customers who live in the area BCA Rungkut Mapan, Surabaya. The technique used is to provide keuisioner to respondents. The results of this study are of six hypotheses, there is a hypothesis that is rejected is no significant effect of service quality on customer loyalty. Limitation in this research is the narrowness of the region and at least a population sample. So for the next study is expected to extend coverage and increase the study sample, which made a research will be better.
\end{abstract}

Keywords: Quality of Services, Corporate Image, Customer Satisfaction, Customer Loyalty.

\begin{abstract}
ABSTRAK
Tujuan penelitian ini adalah untuk mengetahui dan menjelaskan pengaruh signifikan kualitas layanan terhadap citra perusahaan, kualitas layanan terhadap kepuasan pelanggan, kualitas layanan terhadap loyalitas pelanggan, citra perusahaan terhadap loyalitas pelanggan, citra perusahaan terhadap kepuasan pelanggan dan yang terakhir kepuasan pelanggan terhadap loyalitas pelanggan. Jenis penelitian ini adalah explanatory research yang menjelaskan hubungan sebab-akibat antar variabel dengan menggunakan pendekatan kuantitatif. Generalized Structured Component Analysis (GSCA) digunakan sebagai metode analisis data, disertai dengan pengujian hipotesis guna mengetahui pengaruh signifikan terhadap variabel yang sudah ditentukan. Populasi yang diambil sebanyak 55 nasabah BCA yang tinggal di wilayah Rungkut Mapan, Surabaya. Teknik yang digunakan adalah dengan memberikan kuisioner kepada responden. Hasil dari penelitian ini adalah dari enam hipotesis, terdapat satu hipotesis yang ditolak yaitu kualitas layanan tidah berpengaruh signifikan terhadap loyalitas pelanggan. Keterbatasan dalam penelitian ini antara lain sempitnya wilayah populasi dan sedikitnya sampel. Sehingga untuk penelitian berikutnya diharapkan dapat memperluas cakupan wilayah dan memperbanyak sampel penelitian, sehingga penelitian akan semakin baik.
\end{abstract}

Kata kunci: Kualitas Layanan, Citra Perusahaan, Kepuasan Pelanggan, Loyalitas Pelanggan. 


\section{PENDAHULUAN}

Kota Surabaya merupakan pusat bisnis nomor dua setelah jakarta, hal tersebut merupakan peluang bagi perusahaan-perusahaan untuk membuka kantor cabang di Surabaya, tidak terkecuali perbankan yang saat ini sudah menjamur di Surabaya. Banyaknya perbankan yang ada di Surabaya menimbulkan persaingan yang telah membuat setiap bank menyadari suatu kebutuhan untuk memaksimalkan aset demi kelangsungan hidup bank tersebut. Salah satu cara untuk mencapai keadaan tersebut adalah melalui pelayanan maksimal kepada nasabah. Model kualitas layanan perbankan yang popular dan hingga kini banyak dijadikan acuan dalam riset pemasaran adalah SERVQUAL (Service Quality) yang merpakan penilaian atau sikap global yang berkenaan dengan superioritas suatu layanan, sedangkan kepuasan pelanggan adalah respon dari penilaian tersebut. Kualitas layanan harus dimulai dari kebutuhan nasabah dan berakhir pada persepsi nasabah.

Perusahaan yang gagal memuaskan pelanggannya akan menghadapi masalah yang kompleks. Umumnya pelanggan yang tidak puas akan menyampaikan pengalaman buruknya kepada orang lain dan hal tersebut akan menimbulkan kerugian yang cukup besar dari kegagalan memuaskan pelanggan. Oleh karena itu, setiap perusahaan jasa harus mampu mengaplikasikan seluruh ide dan kemampuanya dalam mengelola jasa untuk memuaskan para pelanggannya, karena dengan terpenuhinya kebutuhan pelanggan sesuai dengan harapan, akan diikuti dengan citra positif di mata pelanggan.
Citra yang baik di mata pelanggan akan menimbulkan loyalitas yang tinggi pula. Citra adalah sebuah cerminan dari identitas sebuah organisasi atau perusahaan. Citra tidak dapat diciptakan seperti halnya menciptakan produk, citra akan muncul dengan sendirinya sesuai kesan yang diperoleh publik dari pengetahuan dan pemahaman terhadap sesuatu. Oliver (2007) dalam Andrele (2014) menyatakan bahwa citra korporasi yang kuat adalah aset yang penting dalam era modern saat ini. Semua perusahaan menginginkan citra positif yang melekat pada perusahaanya, yang pada giliranya hal ini juga berpengaruh terhadap produk yang dikeluarkan. Citra merupakan persepsi yang dibangun oleh pelanggan,

Kepuasan pelanggan merupakan tanggung jawab perusahaan, namun membuat pelanggan ingin kembali setelah menggunakan suatu produk. Selain itu, perusahaan juga harus mampu membuat pelanggan untuk menggunakan produk/jasa tersebut secara terusmenerus dan dalam jangka waktu yang panjang, sehingga pelanggan tersebut bisa dikatakan loyal. Loyalitas pelanggan adalah komitmen pelanggan terhadap suatu merek, toko atau pemasok berdasarkan sifat yang sangat positif dalam pembelian jangka panjang (Tjiptono

2000), yang berarti bahwa kesetiaan terhadap merek diperoleh karena adanya kombinasi dari kepuasan dan keluhan.

Dari banyaknya perbankan yang ada di kota Surabaya, peneliti tertarik untuk meneliti bank BCA yang merupakan salah satu bank swasta terbesar di Indonesia dan telah memfasilitasi layanan transaksi perbankan untuk lebih dari 12 juta rekening nasabah melalui 1.042 cabangnya. Tidak hanya dengan produk kartu kredit yang diunggulkan, BCA berkomitmen bahwa semua titik layanan 
sama pentingnya. Salah satunya produk tabungan, kebanyakan konsumen akan memikirkan ulang ketika akan menyimpan uangnya di bank, apakah bank itu bisa dipercaya, apa keuntungan yang mereka berikan, layanan seperti apa yang mereka berikan, dimana kesemua itu bisa diungkapkan melalui citra. Central Asia, SMART memiliki arti Sigap, Menarik, Antusias, Ramah dan Teliti. SMART merupakan bentuk tanggung jawab perusahaan kepada nasabah yang merupakan bagian terpenting dalam roda perusahaan. Adanya standar layanan tersebut memungkinkan setiap karyawanya mampu mengaplikasikan dan menjadikan nasabahnya puas yang akan meningkatkan loyalitas mereka.

\section{LATAR BELAKANG TEORI DAN HIPOTESIS \\ Perbankan}

Bank merupakan salah satu perusahaan yang bergerak di bidang jasa, yang bertujuan untuk mengelola dana dari masyarakat. Pengertian bank menurut undang-undang nomor 10 tahun 1998 tentang perbankan, adalah badan usaha yang menghimpun dana dari masyarakat dalam bentuk simpanan dan menyalurkan kepada masyarakat dalam bentuk kredit maupun bentuk-bentuk lainya dalam rangka meningkatkan taraf hidup rakyat banyak. Pengertian bank menurut SK Menteri Keuangan RI Nomor 792 tahun 1990 adalah suatu badan yang kegiatanya di bidang keuangan, melakukan penghimpunan dan penyaluran dana kepada masyarakat terutama guna membiayai investasi perusahaan.

\section{Jasa}

Menurut Lovelock (2010) jasa adalah "Suatu aktivitas ekonomi yang ditawarkan oleh suatu pihak kepada pihak yang lain". Menurut Kotler (2003) jasa dapat diartikan sebagai "berbagai kegiatan atau manfaat yang dapat ditawarkan oleh suatu pihak ke pihak lain yang secara fisik tidak berwujud dan tidak memberikan pemilikan sesuatu". Definisi lainnya dari jasa berorientasi pada aspek proses dan aktivitas dikemukakan oleh Gronroos (2000) dalam Tjiptono (2006), bahwa jasa adalah "proses yang terdiri atas serangkaian aktivitas intangible yang biasanya (namun tidak harus selalu) terjadi pada interaksi antara pelanggan dan karyawan jasa dan atau sumber daya fisik atau barang dan atau sistem penyedia jasa, yang disediakan sebagai solusi atas masalah pelanggan".

\section{Kualitas Layanan}

Kualitas layanan dapat diartikan sebagai upaya pemenuhan kebutuhan dan keinginan konsumen serta ketepatan

penyampaiannya dalam mengimbangi harapan konsumen (Tjiptono, 2008). Kualitas layanan sering kali dikonseptualiasasikan sebagai perbandingan harapan dengan persepsi kinerja sesungguhnya dari jasa. Menurut Kotler (2003) kualitas adalah totalitas fitur dan karakteristik produk atau jasa yang mempengaruhi kemampuannya untuk memenuhi kebutuhan pelanggan yang dinyatakan dalam usaha meningkatkan kualitas layanan, perusahaan harus meningkatkan komitmen dan kesadaran serta kemampuan para karyawan, terutama mereka yang langsung berhubungan dengan pelanggan.

\section{Kepuasan Pelanggan}

Kualitas layanan yang diberikan kepada perusahaan berdampak pada kepuasan pelanggan, hal tersebut juga akan mempengaruhi profit perusahaan.

Kata kepuasan (satisfaction) sendiri berasal dari bahasa latin "satis" (artinya cukup baik, memadai ) dan "facio" (melakukan atau membuat). Kepuasan bisa diartikan sebagai "upaya pemenuha 


\begin{abstract}
sesuatu" atau "membuat sesuatu

memadai”. Menurut Schnaars (1991) dalam Tjiptono (1995), pada dasarnya tujuan sebuah bisnis adalah menciptakan para pelanggan yang puas. merupakan Citra Perusahaan
\end{abstract}

Citra perusahaan

persepsi tentang suatu perusahaan yang tertanam di benak masyarakat. Menurut Zeithaml and Bitner (1996), "Organizational image as perception of an organization retlected in association held in consumer memory". Untuk membentuk citra yang positif, perusahaan perlu mempublikasikan pesan dirinya kepada lingkungan perusahaan, baik internal maupun eksternal, yaitu pegawai perusahaan, konsumen, supplier, dan lainnya. Perusahaan dapat membentuk citra yang positif dalam benak konsumen (share of mind). Menurut Alma (2005) dalam Saputra (2013), Citra tidak dapat dicetak seperti membuat barang di pabrik, akan tetapi citra adalah kesan yang diperoleh sesuai dengan pengetahuan Dan pemahaman seseorang tentang sesuatu.

Loyalitas Pelanggan

\section{MODEL HIPOTESIS}

Model hipotesis pada penelitian ini dapat dilihat pada Gambar 1.

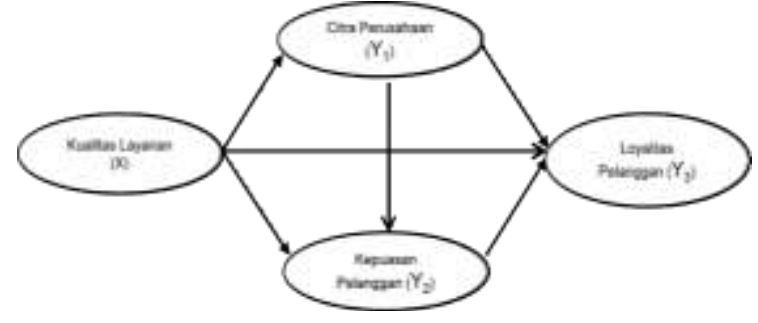

\section{Gambar 1. Model Konseptual}

\section{Keterangan}

H1 : Kualitas layanan memiliki pengaruh signifikan terhadap citra perusahaan.

$\mathrm{H} 2$ : Kualitas layanan memiliki pengaruh signifikan terhadap kepuasan pelanggan.

H3 : Kualitas layanan memiliki pengaruh signifikan terhadap loyalitas pelanggan. H4 : Citra perusahaan memiliki pengaruh signifikan terhadap loyalitas pelanggan.

H5 : Citra perusahaan memiliki pengaruh signifikan terhadap kepuasan pelanggan.

H6 : Kepuasan pelanggan memiliki pengaruh signifikan terhadap loyalitas pelanggan.

\section{METODE PENELITIAN}

Jenis penelitian pada penelitian ini adalah explanatory research, yaitu 


\begin{tabular}{|c|c|}
\hline Menurut Oliver (1999) dalam & penelitian yang menjelaskan hubungan \\
\hline Brunner et al. (2007) menjelaskan & variable-variabel melalui \\
\hline pengertian loyalitas yaitu " $a$ & pengujian hipotesa (Singarimbun \\
\hline commitment to rebuy or repatronize a & Effendi 2011). Penelitian ini menggunakan \\
\hline preferred product/service consistently in & metode analisis Generalized Structured \\
\hline the future, thereby causing repetitive & Analysis (GSCA) disertai \\
\hline same-brand or same brand-set purchasing, & dengan pengujian \\
\hline despite situational influences and & mengetahui pengaruh signifikan terhadap \\
\hline marketing efforts having the potential to & variabel yang sudah ditentukan. Populasi \\
\hline cause switching behavior". Dari definisi di & yang diambil sebanyak 55 nasabah \\
\hline atas dapat diartikan bahwa loyalitas & yang tinggal di wilayah Rungkut Mapan, \\
\hline merupakan komitmen yang dipegang & Surabaya. Teknik yang digunakan adalah \\
\hline teguh untuk membeli ulang secara & dengan memberikan kuisioner kepada \\
\hline konsisten barang/jasa di masa yang akan & Penilaian instrument dalam \\
\hline datang. & menggunakan \\
\hline
\end{tabular}


dalam penelitian ini didapati bahwa semua butir pernyataan yang digunakan valid, ditunjukkan nilai rhitung > rtabel dengan nilai signifikansi masing-masing item pernyataan $0,000-0,004<$ 0,05 sehingga instrumen dalam penelitian ini dapat digunakan sebagai alat pengumpul data yang baik. Dari hasil uji reliabilitas diketahui bahwa nilai reliabilitas yang dicapai pada masing-masing variabel semuanya lebih besar dari 0,6. Dengan demikian instrumen yang digunakan dalam penelitian ini dapat dikatakan reliabel dan handal sebagai alat ukur.

\section{HASIL DAN PEMBAHASAN}

Tabel 1. Model Fit

\begin{tabular}{|c|c|}
\hline \multicolumn{2}{|c|}{ Model Fit } \\
\hline FIT & 0.653 \\
\hline AFIT & 0.638 \\
\hline
\end{tabular}

FIT $=0.653$

FIT menunjukkan varian total dari semua variabel yang dapat dijelaskan oleh model tertentu (Solimun 2012). Nilai FIT

berkisar dari 0 sampai 1 . Jadi, model yang terbentuk dapat menjelaskan semua variabel yang ada sebesar $65.3 \%$. Keragaman Kualitas Layanan, Citra Perusahaan, Kepuasan Pelanggan dan Loyalitas Pelanggan yang dapat dijelaskan oleh model adalah sebesar $65.3 \%$ yang menunjukkan bahwa model sangat baik, karena dapat menjelaskan keragaman data dengan nilai lebih besar dari $50 \%$.

\section{$\mathrm{AFIT}=\mathbf{0 . 6 3 8}$}

Adjusted dari FIT hampir sama dengan

FIT. Namun, karena variabel yang mempengaruhi loyalitas tidak hanya satu melainkan tiga variavel, sehingga akan lebih baik interpretasi tentang ketepatan model menggunakan FIT yang sudah terkoreksi atau menggunakan AFIT.
Karena semakin banyak variabel yang mempengaruhi maka nilai FIT akan semakin besar karena proporsi keragaman juga akan meningkat sehingga untuk menyesuaikan dengan variabel yang ada dapat menggunakan FIT yang sudah terkoreksi. Jika dilihat dari nilai AFIT, keragaman Kualitas Layanan, Citra Perusahaan, Kepuasan Pelanggan dan juga Loyalitas Pelanggan dapat dijelaskan oleh model sebesar $63.8 \%$ dan sisanya (36.2\%) dapat dijelaskan oleh variabel lain. Hal tersebut menunjukkan jika dilihat dari nilai AFIT yang diperoleh, model yang terbentuk sudah baik.

Tabel 2. Pengujian Hipotesis

\begin{tabular}{|c|c|c|c|c|}
\hline & $\begin{array}{c}\text { Esti } \\
\text { ma }\end{array}$ & $\mathbf{S}$ & $\begin{array}{l}\text { Critic } \\
\text { al }\end{array}$ & $\begin{array}{l}\text { Kesimpula } \\
\text { n }\end{array}$ \\
\hline $\begin{array}{l}\text { Kualitas } \\
\text { Layanan - } \\
>\text { Citra } \\
\text { Perusahaan }\end{array}$ & 0.566 & 0.202 & $2.8^{*}$ & $\begin{array}{l}\text { Berpengaru } \\
\text { h positif } \\
\text { dan } \\
\text { signifikan }\end{array}$ \\
\hline $\begin{array}{l}\text { Kualitas } \\
\text { Layanan - } \\
\text { > Kepuasan } \\
\text { Pelanggan }\end{array}$ & 0.447 & 0.167 & $2.67 *$ & $\begin{array}{l}\text { Berpengaru } \\
\text { h positif } \\
\text { dan } \\
\text { signifika }\end{array}$ \\
\hline $\begin{array}{l}\text { Kualitas } \\
\text { Layanan - } \\
\text { > Loyalitas }\end{array}$ & 0.230 & 0.121 & 1.91 & $\begin{array}{c}\text { Berpengaru } \\
\text { h } \\
\text { positif } \\
\text { dan tidak }\end{array}$ \\
\hline $\begin{array}{l}\text { Citra } \\
\text { Perusahaan } \\
\text {-> } \\
\text { Lovalitas }\end{array}$ & 0.311 & 0.117 & $2.67 *$ & $\begin{array}{c}\text { dan tidak } \\
\text { Berpengaru } \\
\text { h } \\
\text { positif } \\
\text { dan }\end{array}$ \\
\hline $\begin{array}{l}\text { Citra } \\
\text { Perusahaan } \\
\text {-> Kepuasan } \\
\text { Pelanggan }\end{array}$ & 0.485 & 0.106 & $4.59 *$ & $\begin{array}{l}\text { Berpengaru } \\
\text { h positif } \\
\text { dan } \\
\text { signifika } \\
\end{array}$ \\
\hline $\begin{array}{l}\text { Kepuasan } \\
\text { Pelanggan } \\
> \\
\text { Lovalitas }\end{array}$ & 0.267 & 0.119 & $2.24^{*}$ & $\begin{array}{l}\text { Berpengaru } \\
\text { h positif } \\
\text { dan } \\
\text { signifika } \\
\end{array}$ \\
\hline
\end{tabular}

Hipotesis H1 : Kualitas Layanan berpengaruh signifikan terhadap Citra Perusahaan.

Penelitian ini menyatakan bahwa Kualitas Layanan berpengaruh signifikan 
terhadap Citra Perusahaan dapat diterima. Dari hasil pengujian antar variabel menunjukkan bahwa Kualitas Layanan berpengaruh signifikan terhadap Citra Perusahaan, artinya semakin bagus kualitas layanan yang diberikan oleh suatu perusahaan jasa khususnya BCA, maka semakin bagus pula citra perusahaan tersebut. Hasil pengujian model menggunakan GSCA menunjukkan pengaruh positif dan signifikan dengan nilai critical ratio 2.8 dan koefisien jalur sebesar

0.566. Hasil penelitian ini konsisten dengan hasil penelitian yang dilakukan oleh Ryu et al. (2012), Fullant et al. (2008) dan Alfin et al. (2013).

Kesimpulan yang diperoleh dari diterimanya hipotesis ini adalah jika seluruh anggota dalam manajemen khususnya BCA Rungkut mapan mampu bekerja sama dalam meningkatkan kualitas layanan di berbagai aspek seperti ketersediaan bukti fisik yang baik di kantor, kemampuan dan intelegensi karyawan, daya tanggap karyawan terhadap nasabah maupun lingkungan sekitar, menjalin hubungan baik dengan nasabah maupun masyarakat sekitar akan mampu meningkatkan citra BCA Rungkut Mapan di mata nasabah maupun masyarakat sekitar, serta mampu memberikan kontribusi kepada BCA secara luas dalam hal peningkatan citra perusahaan melalui kualitas layanan yang baik. Sebaliknya, jika manajemen tidak mampu menjaga kualitas layanan, maka akan menciptakan citra negatif di mata nasabah maupun masyarakat sekitar, bahkan akan menjadikan citra BCA buruk secara keseluruhan.

Hipotesis H2 : Kualitas Layanan berpengaruh signifikan terhadap Kepuasan Pelanggan.
Penelitian ini menyatakan bahwa Kualitas Layanan berpengaruh signifikan terhadap kepuasan pelanggan dapat diterima. Dari hasil pengujian antar variabel menunjukkan bahwa Kualitas Layanan berpengaruh signifikan terhadap kepuasan pelanggan, artinya makin bagus kualitas layanan yang diberikan oleh suatu perusahaan jasa khususnya BCA, maka semakin tinggi pula kepuasan yang dirasakan oleh nasabah. Hasil pengujian model menggunakan GSCA menunjukkan pengaruh positif dan signifikan dengan nilai critical ratio 2.67 dan koefisien jalur sebesar 0.447. Hasil ini sesuai dengan hasil penelitian yang dilakukan oleh I Gede Mahatma dan Sik Sumaedi (2012), Alfin et al. (2013), Abd-El-Salam et al. (2013).

Kesimpulan yang diperoleh dari diterimanya hipotesis ini adalah jika manajemen mampu menjaga standart kualitas layanan dengan baik serta menyesuaikan dengan lingkungan, maka kepuasan secara keseluruhan pun akan didapat oleh manajemen BCA Rungkut Mapan. Sebaliknya, jika ada hal-hal tertentu dari kualitas layanan yang tidak bisa dipenuhi oleh manajemen, maka nasabah pun akan merasa tidak puas dan akibat kebelakangnya adalah mereka tidak akan lagi melakukan transaksi di BCA Rungkut Mapan dengan membiarkan rekeningnya tidak aktif (dormant account) akan tertutup otomatis oleh sistem atau mereka akan langsung menutup rekening mereka akibat ketidakpuasan tersebut.

Hipotesis H3 : Kualitas Layanan berpengaruh signifikan terhadap Loyalitas Pelanggan.

Penelitian ini menyatakan bahwa kualitas layanan berpengaruh signifikan terhadap loyalitas pelanggan tidak dapat diterima. Dari hasil pengujian antar variabel menunjukkan bahwa kualitas 
layanan memiliki pengaruh terhadap loyalitas pelanggan namun tidak signifikan, artinya makin bagus kualitas layanan yang diberikan oleh suatu perusahaan jasa khususnya BCA, tidak selalu diikuti dengan meningkatnya loyalitas pelanggan. Hasil pengujian model menggunakan GSCA menunjukkan pengaruh positif dengan nilai critical ratio 1.91 dan koefisien jalur sebesar 0.230. Hasil ini sesuai dengan hasil penelitian yang dilakukan oleh Abd- El-Salam et al. (2013).

Kesimpulan yang diperoleh dari diterimanya hipotesis ini adalah kualitas layanan berpengaruh tidak signifikan terhadap loyalitas pelanggan disebabkan oleh beberapa hal, dilihat dari karakteristik responden berdasarkan jenis pekerjaan, kebanyakan warga sekitar Rungkut Mapan berprofesi sebagai wiraswasta dan karyawan swasta. Responden wiraswasta kebanyakan adalah seorang pemilik usaha yang bergerak dibidang perdagangan, baik perdagangan kebutuhan pokok higga onderdil mobil dan mereka kebanyakan tetap berada di toko untuk mengendalikan dan mengawasi transaksi, sehingga untuk melakukan transaksi keuangan seperti menyetor pendapatan harian, mengambil uang maupun mentransfer uang, mereka memiliki kecenderungan menyuruh orang yang dipercaya sebagai kurir yang pergi ke bank untuk melakukan transaksi keuangan dengan diberi surat kuasa terlebuh dahulu. Hal tersebut membuat para pemilik jarang datang ke bank dan bertatap muka langsung untuk melakukan transaksi keuangan. Namun, kebanyakan dari mereka tetap loyal, karena pihak manajemen bank mampu menjaga hubungan baik dengan nasabah dengan cara mengirimkan tim marketing untuk sekedar memberikan hadiah atau memberikan informasiinformasi tentang perbankan, sehingga nasabah masih tetap merasa diperhatikan.
Karakteristik responden berikutnya adalah karyawan swasta, dimana saat ini banyak bank yang menggunakan BCA sebagai media pembayaran gaji (payroll), sehingga mau tidak mau karyawan yang bekerja di perusahaaan tersebut harus memiliki rekening di bank BCA agar bisa menerima gajinya. Hal ini membuat nasabah yang bekerja sebagai karyawan swasta membuka rekening hanya sebagai persyaratan saja, bukan karena keinginan pribadi atau karena tahu kelebihan dari BCA. Selain itu karyawan swasta yang bekerja di perusahaan yang ditempatkan di bagian tertentu dan mempunyai jam kerja yang ketat tidak bisa melakukan transaksi di bank, karena ketentuan 8 jam kerja perhari, sedangkan bank hanya beroprasi hingga pukul 15.00, sehingga mereka hanya bisa menggunakan fasilitas online banking saja.

Hipotesis H4 : Citra Perusahaan berpengaruh signifikan terhadap Loyalitas Pelanggan.

Penelitian ini menyatakan bahwa Citra Perusahaan berpengaruh signifikan terhadap Loyalitas pelanggan dapat diterima. Dari hasil pengujian antar variabel menunjukkan bahwa Citra Perusahaan berpengaruh signifikan terhadap Loyalitas pelanggan, artinya makin bagus Citra yang dimiliki suatu perusahaan, maka akan semakin tinggi pula loyalitas nasabah terhadap perusahaan tersebut. Hasil pengujian model menggunakan GSCA menunjukkan pengaruh positif dan signifikan dengan nilai critical ratio 4.59 dan koefisien jalur sebesar 0.485. Hasil ini sesuai dengan hasil penelitian yang dilakukan oleh Brunner et al. (2007), Kandampully et al. (2000).

Kesimpulan yang diperoleh dari
diterimanya hipotesis ini adalah BCA

Kesimpulan yang diperoleh dari diterimanya hipotesis ini adalah BCA 
secara keseluruhan memiliki pencitraan yang bagus di mata masyarakat yang banyak di tunjukkan dari berbagai penghargaan yang berhubungan dengan pelanggan seperti 2013 Banking Service Excellence, Corporate Image Award 2013, Indonesia Service Quality Award 2013, Indonesian Bank Loyalty Award 2013 tentang loyalitas dan masih banyak lagi. Penghargaan tersebut membuktikan BCA memiliki citra yang baik di mata masyarakat secara keseluruhan, tidak terkecuali dengan BCA Rungkut Mapan. Dari citra yang baik itulah akan muncul niat beli atau niat penggunaan, dan akan menciptakan pengalaman yang akan membentuk sikap loyal terhadap BCA cabang Rungkut Mapan.

Hipotesis H5 : Citra Perusahaan berpengaruh signifikan terhadap Kepuasan Pelanggan

Penelitian ini menyatakan bahwa Citra Perusahaan berpengaruh signifikan terhadap kepuasan pelanggan dapat diterima. Dari hasil pengujian antar variabel menunjukkan bahwa Citra perusahaan berpengaruh signifikan terhadap kepuasan pelanggan, artinya makin bagus citra yang ditampilkan oleh suatu perusahaan, maka akan semakin tinggi kepuasan yang akan dirasakan oleh nasabah. Hasil pengujian model menggunakan GSCA menunjukkan pengaruh positif dan signifikan dengan nilai critical ratio 2.67 dan koefisien jalur sebesar 0.311. Hasil ini sesuai dengan hasil penelitian yang dilakukan oleh Ryu et al. (2012), Kandampully et al. (2000), Alfin et al. (2013).

Kesimpulan yang diperoleh dari diterimanya hipotesis ini adalah dengan peningkatan citra perusahaan dari berbagai aspek seperti kualitas layanan dan kualitas produk akan mampu meningkatkan citra perusahaan dan menciptakan suatu kepuasan bagi pelanggan. Responden mengetahui informasi tentang pencitraan BCA dari berbagai sumber(media cetak maupun elektronik), dari situ akan ada dorongan untuk mencoba menggunakan, jika layanan yang diterima sesuai dengan pencitraan yang mereka ketahui, maka akan menciptakan kepuasan. Sebaliknya, jika ternyata yang mereka rasakan berbeda jauh / tidak sesuai dengan pencitraan yang mereka ketahui, maka mereka akan merasa sangat tidak puas, efek buruknya mereka akan menyebarkan informasi tentang pengalamanya itu kepada orang lain dan hal tersebut akan sangat merugikan pihak manajemen, BCA Rungkut Mapan khususnya.

Hipotesis H6 : Kepuasan Pelanggan berpengaruh signifikan terhadap Loyalotas Pelanggan.

Penelitian ini menyatakan bahwa Kepuasan Pelanggan berpengaruh signifikan terhadap Loyalitas pelanggan dapat diterima. Dari hasil pengujian antar variabel menunjukkan bahwa kepuasan pelanggan berpengaruh signifikan terhadap loyalitas pelanggan, artinya makin tinggi kepuasan yang dirasakan pelanggan, maka akan semakin meningkat pula loyalitas dari pelanggan tersebut. Hasil pengujian model menggunakan GSCA menunjukkan pengaruh positif dan signifikan dengan nilai critical ratio 2.24 dan koefisien jalur sebesar 0.267. Hasil ini sesuai dengan hasil penelitian yang dilakukan oleh I Gede Mahatma dan Sik Sumaedi (2012), Alfin et al. (2013), Abd-El- Salam et al. (2013), Ryu et al.(2012), Brunner et al. (2007), Kandampully et al. (2000).

Kesimpulan yang diperoleh dari diterimanya hipotesis ini adalah hubungan 
antara kepuasan pelanggan dan loyalitas pelanggan sangat erat, dimana, jika nasabah puas maka mereka akan menggunakan secara berulang. Sebaliknya, jika mereka tidak puas, mereka tidak hanya akan berhenti menggunakan, namun bukan tidak mungkin mereka akan menceritakan pengalamannya kepada orang lain yang akan berakibat kurang baik bagi perusahaan. Kepuasan dari BCA Rungkut Mapan tercermin dalam banyak hal, seperti kepuasan akan perhatian yang diberikan karyawan secara personal dengan memberikan hadiah saat berulang tahun atau saat hari raya etnis tionghoa. Hal-hal kecil tersebut dianggap berarti oleh nasabah, sehingga secara tidak langsung nasabah akan menunjukkan sikap loyalnya kepada BCA Rungkut Mapan seperti dengan selalu mengikuti program-program produk terbaru dari BCA dan lain sebagainya.

\section{Keterbatasan Penelitian}

Penelitian ini mendasarkan hasil pada uji statistik yang telah dilakukan, akan tetapi terdapat beberapa keterbatasan dalam penelitian ini. Keterbatasan tersebut antara lain:

1. Penelitian ini bukan merupakan penelitian eksperimen atau bersifat longitudinal (penelitian jangka panjang) akan tetapi penelitian eksplanatori dan dalam jangka waktu singkat. Sehingga penelitian ini kurang mampu menggambarkan peristiwa dalam satu periode.

2. Penelitian ini hanya berfokus pada satu kawasan yaitu kawasan Rungkut Mapan yang terbagi menjadi empat bagian, yakni Rungkut Mapan Barat, Rungkut Mapan Timur, Rungkut Mapan Utara, Rungkut Mapan Tengah, sehingga tidak menutup kemungkinan hasil penelitian tidak dapat digeneralisasikan pada lokasi yang lain.

3. Sampel pada penelitian ini memiliki ukuran yang kecil, sehingga tidak menutup kemungkinan bahwa dapat membatasi generalisasi hasil penelitian.

4. Penelitian ini hanya menguji hubungan langsung antar variabel tanpa menggunakan moderasi, hal ini menjadi keterbatasan peneliti untuk menjelaskan konsep secara utuh.

\section{KESIMPULAN DAN SARAN Kesimpulan}

1. Terdapat pengaruh yang signifikan antara Kualitas Layanan terhadap Citra Perusahaan. Semakin tinggi Kualitas Layanan akan semakin meningkatkan Citra Perusahaan. Nasabah menilai bahwa layanan yang diterima sudah sesuai dengan yang diharapkan, baik dari segi fisik, daya tanggap karyawan, dan kemampuan dalam memberikan informasi, dari keseluruhan layanan yang diterima akan lebih meningkatkan image Perusahaan.

2. Terdapat pengaruh yang signifikan antara Kualitas Layanan terhadap Kepuasan Pelanggan. Semakin tinggi Kualitas Layanan akan semakin meningkatkan Kepuasan Pelanggan. Kepuasan akan tercipta jika harapan sudah sesuai dengan kenyataan, Nasabah BCA Rungkut Mapan Sudah puas terhadap keseluruhan pelayanan, karena yang diharapkan oleh nasabah sudah terpenuhi.

3. Kualitas Layanan berpengaruh tidak signifikan terhadap Loyalitas Pelanggan. Semakin baik Kualitas Layanan yang diterima diikuti meningkatnya loyalitas, namun tidak terjadi secara signifikan. Nasabah cenderung mengesampingkan aspek kualitas layanan, mereka lebih memperhatikan aspek lain seperti biaya 
administrasi yang mahal, pinalti yang dikenakan jika saldo dibawah batas minimum, sehingga tidak semua pelanggan akan berperilaku loyal terhadap BCA KCP Rungkut Mapan.

4. Terdapat pengaruh yang signifikan antara Citra Perusahaan terhadap Kepuasan Pelanggan. Semakin tinggi Citra Perusahaan maka akan diikuti meningkatnya Kepuasan Pelanggan. Citra yang baik akan menciptakan persepsi baik pula kepada nasabah. BCA Rungkut Mapan memiliki Citra yang baik atau tidak memiliki track record yang buruk terutama dari segi kualitas layanan, sehingga Citra yang baik itu akan mampu membuat pelanggan merasa puas bertransaksi di BCA Rungkut Mapan.

5. Terdapat pengaruh yang signifikan antara Citra Perusahaan terhadap Loyalitas Pelanggan. Semakin tinggi Citra Perusahaan akan semakin meningkatkan Loyalitas Pelanggan. Citra baik yang dimiliki oleh BCA mampu meningkatkan nasabah untuk kembali melakukan transaksi di cabang Rungkut mapan, disamping dari pelayanan yang diterima.

6. Terdapat pengaruh yang signifikan antara Kepuasan Pelanggan dengan Loyalitas Pelanggan. Semakin tinggi kepuasan yang dirasakan, maka akan semakin meningkat pula Loyalitas Pelanggan tersebut. Loyalitas pelanggan BCA Rungkut Mapan muncul karena nasabah sudah merasakan puas terhadap transaksi sebelumnya, sehingga ingin kembali melakukan transaksi di BCA Rungkut Mapan.

\section{Saran}

Dari hasil penelitian, diajukan beberapa saran yang bisa digunakan sebagai bahan pertimbangan bagi peneliti lain dalam bidang kualitas layanan yang akan melakukan penelitian lanjutan, selain itu hasil penelitian ini diharapkan memberikan kontribusi praktis, baik bagi BCA Rungkut Mapan, berupa saran-saran konkrit yang mungkin dapat direalisasikan, antara lain :

1. Disarankan pada penelitian selanjutnya dapat meneliti lebih dari 1 jenis perbankan, agar penelitian dapat digeneralisasikan menjadi lebih luas.

2. Penelitian ini memungkinkan untuk mengembangkan konsep dan menambah variabel lain yang dianggap perlu dan menyempurnakan penelitian dengan penambahan variabel kualitas produk pada BCA. Selain itu dalam penelitian ini masih memungkinkan penambahan indikator dalam setiap variabelnya untuk lebih mewakili obyek yang digunakan.

3. Penambahan jumlah sampel akan memberikan hasil yang berbeda pada hasil penelitian. Karena dengan sampel yang lebih banyak akan terdapat banyak kemungkinan temuan penelitian terbaru yang berguna bagi acuan penelitian- penelitian dimasa yang akan datang.

\section{DAFTAR PUSTAKA}

Aaker, David A dan Joanchimstaler, E.

1991. Managing Brand Equity: Capitalizing on the Value of a Brand Name. New York: The Free Press.

Abd-El-Salam, Eman Mohammed, Ayman Yehia Shawky and Tawfik El-Nahas.2013. "The impact of corporate image and reputation on service quality, customer satisfaction and customer loyalty:testing the mediating role.Case analysis in an international service company. The Business \& Nanagement review.Vol.3 No.2

Alfin, Rita, Taher Alhabsji, Umar Nimran, Suharyono. 2013." Effect of Service Quality and Product Quality To Corporate Image, Customer's Satisfaction and Customer's 
Trust". IOSR Journal of Business and Management (IOSR-JBM). Vol. 9 No. 6, pp

Alfin, Rita. (2013). Pengaruh kualitas layanan dan kualitas produk terhadap citra perusahaan, kepuasan pelanggan dan kepercayaan pelanggan. Fakultas ilmu administrasi bisnis Brawijaya Malang.disertasi tidak di terbitkan.

Armstrong, dan Kotler 2003, Dasar-dasar Pemasaran, Jilid 1, Edisi Kesembilan,. Penerbit PT. Jakarta: . Indeks Gramedia.

Arikunto, Suharsimi. 2006. Prosedur Penelitian Suatu Pendekatan Praktek. Jakarta : Rineka Cipta.

Andreassen, T. W.; and Lanseng, E., (1997),"The principal's and agents' contribution to customer loyalty within an integrated service distribution channel: An external perspective", European Journal of Marketing, Vol. 31, No.7, pp. 487 - 503.

Andreassen, T. W.; and Lindestad B., (1998) 1998),"Customer loyalty and complex services: The impact of corporate image on quality, customer satisfaction and loyalty for customers with varying degrees of service expertise",International Journal of Service Industry Management, Vol. 9, No.1, pp. 7 23.

Bravo, R.; Montaner, T.; Pina, J.M., (2009), "The role of bank image for customers versus

Brunner, Thomas A., Markus Sto“cklin and Klaus Opwis.2007." Satisfaction, image and loyalty: new versus experienced customers". European Journal of Marketing. Vol. 42 No. 9/10.

Cronin, J.J. and Taylor, S.A. (1992), "Measuring service quality: a re- examination and extension”, Journal of Marketing, Vol. 56, pp. 5568
Dowling, G.R. and Uncles, M. (1997), "Do customer loyalty programs really work?",Sloan Management Review, Vol. 38

No. 4, pp. 71-82.

Durianto, Darmadi (2001), "Strategi Menaklukkan Pasar Melalui Riset Ekuitas dan Perilaku Merek",Jakarta :Gramedia Pustaka Utama.

Faullant, Rita, Kurt Matzler and Johann Fu“ller. 2008." The impact of satisfaction and image on loyalty: the case of Alpine ski resorts". Managing Service Quality. Vol. 18

No. 2.

Fombrun, C. (1996), Reputation. Realizing Value from the Corporate Image, Harvard Business School Press, Boston, MA

Fornell, C. (1992), "A national customer satisfaction barometer: the Swedish experience",Journal of Marketing, Vol. 56

No. 1, pp. 6-21

Ghozali, Imam dan Fuad. 2005. Structural Equational Modeling. Semarang : Badan Penerbit Universitas Diponegoro.

2010. Generalized Structured Component Analysis (GSCA). Semarang : Badan Penerbit Universitas Diponegoro.

Gummesson, E. and Grönroos, C. (1988), "Quality of services: lessons from the product sector", in Surprenant, C. (Ed.), Add Value to Your Service, American Marketing Association, Chicago, IL

Grönroos, C. (2000) Service Management and Marketing: A Customer Relationship Approach. Chichester: Wiley.

Hatch, M.J., Schultz, M. and Williamson, J. (2003), "Bringing the corporation into corporate branding", European Journal of Marketing, Vol. 37 No. 7/8, pp. 1041-64 
Hong, S.C., and Goo, Y.J.J. (2004), "A causal model of customer loyalty in professional service firms: an empirical study", International Journal of Management, Vol. 21 No. 4, pp.531-540

Kandampully, Jay and Dwi Suhartanto.

2000. "Customer Loyalty in the hotel industry:the role of customer satisfaction and image". International journal of Contemporary Hospitality Management.346-351.

Keisidou, Elissavet, Lazaros Sarigiannidis and Dimitrios I. Maditinos.2013. "Customer satisfaction, loyalty and financial performance, A holistic approach of the Greek banking sector". International Journal of Bank Marketing Vol. 31 No. 4.

Kotler, P. 2000. "Marketing Management". The Millenium ed, Upper saddle River, Prentice Hall, Inc. New Jersey.

Kuncoro, Mudrajad. 2003. Metode Riset untuk Bisnis \& Ekonomi. Jakarta :Erlangga.

Liang kheng, Lo, Osman Mahamad, T.Ramayah, and Rahim Mosahab.

2010.'The impact of service quality on customer loyalty : A Study of Banks in Penang, Malaysia". International Journal of Marketing Studies. Vol.2 No.2.

Lovelock. Christoper dan Wright. Lauren.

2007. Manajemen Pemasaran Jasa. Terjemahan oleh Dian Wulandari. Edisi ketujuh. Jakarta : Erlangga.

Mahatma yuda Bakti, I Gede and Sik Sumaedi.2012."An analysis of library customer loyalty, The role of service quality and customer satisfaction, a case study in Indonesia.Library management. Vol.34 No.6/7.

Nastiti.Sri dan Wisnu.Dicky.2004.Statistika Bisnis.umm.
Nazir, M. (2009). Metode Pelitian. Bogor: Ghalia Indonesia.

Oliver, R. (1999), "Whence consumer loyalty?",Journal of Marketing, Vol. 63, pp. 33-44

Parasuraman, A., Zeithaml, V.A. and Berry, L.L. (1985), "A conceptual model of service quality and its implication for future research",Journal of Marketing, Vol. 49, pp. 41-50.

Rangkuti, Freddy 2002. Measuring Customer Satisfaction. Jakarta: Gramedia Pustaka Utama.

Ryu, Kisang, Hye-Rin Lee and Woo Gon Kim. 2012."The influence of the quality of the physical environment, food, and service on restaurant image, customer perceived value, customer satisfaction, and behavioral intentions".International journal of Contemporary Hospitality Management. Vol.24 No.2.

Sarstedt, M. ; Wilczynski, P.; Melewar, T.C., (2012), "Measuring reputation in global markets-A comparison of reputation measures' convergent and criterion validities", Journal of World Business, under press, pp.1-11.

Schnaars, S.P. 1991. Maeketing Strategy. A Customer Driven Aproach. New York: The Free Press.

Sekaran, U. (2006). Metode Penelitian untuk Bisnis (4 ed.). Jakarta: Salemba Empat.

Singarimbun dan Effendi . 2011. Metode Penelitian Survai. Jakarta: LP3ES..

Solimun, 2008. Memahami Model Kuantitatif Mutakhir :Struktural Equation Modelling \& Partial Least Square. Program Studi Statistika FMIPA. Universitas Brawijaya. Malang. 
Sugiyono. (2009). Metode Penelitian Bisnis.

Bandung: Alfabeta.

$$
\text { . 2012. Metode Penelitian }
$$

Bisnis. Bandung : Alfabeta.

Sultan, Parves and Ho Yin Wong.2012." Service quality in a higher education context: an integrated model". Asia Pacific Journal of Marketing and Logistics. Vol. 24

No. 5.

Tat Huei, Cham and Yalini Easvaralingam.

2011. "Perceptions of Service Quality, Corporate Image, and Customer Loyality in the Hotel Industry of Malaysia". The $2^{\text {nd }}$ . 2008. Service Management.

Malang : Bayumedia Publishing.

II. Yogyakarta : Andi.

Yamin, Sofyan dan Heri, Kurniawan. 2009. Structural Equational Modelling. Jakarta : Salemba Infotek.

Zeithaml, V.A., Berry, L.L. and Parasuraman, A. (1996), "The behavioral consequences of service quality",Journal of Marketing, Vol. 60 No. 2.

\section{Sumber Internet}

http://www.bca.co.id/id/about/hubunganmedia/2013 Mar 04 Tabungan Dan Inter net_Banking_BCA_Raih_Consumer_3000
International Research Symposium in Service ManagementYogyakarta, INDONESIA, 26 30.

Tjiptono, Fandy dan Chandra, Gregorius.

2005. Service Quality and Satisfaction. Yogjakarta : Andi.

Tjiptono, Fandy. 2005.Brand Management

\& Strategy. Yogyakarta: Andi.

_Award_2013/2013_Mar_04_Tabungan_D an_Internet_Banking_BCA_Raih_Consum er_3000_Award_2013.jsp.

http://rungkut-surabaya.org/data-dina7mis/. 